\title{
A Self-Guided Library Tour for the
}

Biosciences

\begin{abstract}
Replacement of a conventional, staff-guided library tour for graduate students in the biosciences by a self-guided tour seems to have encouraged individual student effort, has allowed for development of individual interests during the tour, and has greatly reduced the time required for staff participation. Self-guided tours are easily developed and installed and merit general consideration.
\end{abstract}

$\mathrm{T}$ HE PRIMARY LITERATURE of the biosciences, with a hard core of thirty-five hundred extant journal titles ${ }^{1}$ is enormous. Beginning graduate students need to be acquainted with its fundamental nature, with its diversity and structural complexity, and with efficient methods for its use. Each September, in an intensive study program of four weeks, new biology graduate students at the University of Delaware are made aware of the important journals in subdisciplines of their greatest interest, learn to recognize and analyze the parts of a research paper, become familiar with the most important bibliographic aids, and embark on projects designed to develop understanding in specific areas of scientific investigation. These projects involve critical reading, the writing of abstracts, and exhaustive literature searches. For years these exercises began with a tour of the university library so that students would know the location of available services. Tours involved groups of eight to twelve students, re-

\footnotetext{
${ }^{1}$ Raymund L. Zwemer, in Fred S. Howard (ed.) Biological Sciences Serial Publications, a World List 1950-1954 (Philadelphia: Biological Abstracts, 1955), p. $v$.
}

Dr. Ronkin is with the Office of International Science Activities in the National Science Foundation. He acknowledges the encouragement of Clifton F. Giles, Jr., in the preparation of this paper. quired about an hour, and were conducted by the professional staff of the library. Inadequacies of the tour became evident when responses were analyzed to a questionnaire completed by the students at the end of the academic year in which the tour had been the first exercise. These shortcomings included (1) emphasis on services (microfilm: Readers' Guide to Periodical Literature) which are of comparatively little use to scholars in biology; (2) failure to draw attention to certain especially useful items (the Xerox machine, the journals shelved with U.S. government documents); (3) inability of students at the rear of the group to see and hear; (4) lack of opportunity to handle the items shown and to examine them closely, thus failing to satisfy curiosity at the moment of its provocation by the guide; and (5) lack of opportunity to notice and explore items of special interest to individual students. Furthermore, planning and guiding the tour required extra time of the library staff, often in the evening.

To improve the library orientation at Delaware it was first assumed that a tour is desirable and that it is best planned by a member of the faculty skilled in graduate pedagogy and familiar with the varied needs of embryonic scholars in his field. It also seemed clear that the diversity of inter- 
ests at this level of training requires that students tour as individuals and not in a group. Finally, it was apparent that a live guide often prevents a direct confrontation of the student with the library materials: during the tour the student could neither handle the materials himself nor seek answers prompted by his emerging special interests. For these reasons an individual, self-guided tour was designed and installed.

The first draft of instructions for the tour was written by the instructor in his office in one sitting. Having prepared the draft, the instructor toured with it in hand, correcting errors and clarifying ambiguities as he walked ( 45 minutes). A member of the library's reference staff kindly provided final review (15 minutes), after which mimeograph stencils were cut and copies were produced for distribution to students.

Beginning at the main entrance, the tour route included most of the public areas of the building; the final sentence of the instructions propelled the student through the exit turnstile and out. The instructions followed the detailed, pedantic style of the European tourist guidebooks. While the student was required to identify seventy-eight features and services (including only seven specific publications), he was also encouraged to browse somewhat during the tour. The following materials were included as supplements: (1) a plan of the main floor with arrows showing the first part of the route; (2) some easy retrieval problems, so worded that the usefulness of this newly acquired skill would be obvious to the student (one-half page); (3) a statistical summary of library user services and a brief description of the interlibrary loan service, the processes of acquisition and cataloging, and the annual budget (all on one page); and (4) an analysis of the biosciences portion of Class Q of the Library of Congress classification system (one page). The latter feature was necessary because most of the students were familiar only with the Dewey system, from their undergraduate experience at other institutions, and because the library's posted classification schedules were insufficiently detailed for the purpose.

During the first year of student use it was observed that the center of purposeful effort shifted somewhat from the staff toward the individual student, where it belongs. The new tour evidently required about twice as much time as the old one. It could be scheduled entirely at the convenience of the student, who might elect to divide the tour into two or more sessions. There were indications that the students now require much less help than in former years in locating services at the time of actual use and that many students remember longer the items they saw on the tour. Once written, the instructions for the tour were likely to require little or no revision for at least several years.

There seem to be good reasons for designing self-guiding tours for graduate students in the biosciences and perhaps in other scholarly disciplines, and even for certain groups of undergraduates, especially when the instructions are written by faculty members who teach at these levels. Christensen and Palmer ${ }^{2}$ have remarked: "Instructors should be aware of a strange phenomenon whereby the student may consider acquisition of a learning program nearly equivalent to mastery of the subject." In concurring, the experience at Delaware suggests that mimeographed instructions for tours not be made freely available at the library service desk, but used instead as specific assignments by course instructors, who subsequently test the students for understanding of their subject gained through effective use of the acquired bibliographic skills.

\footnotetext{
${ }^{2}$ Halvor N. Christensen and Graham A. Palmer, Enzyme Kinetics, a Learning Program for Students of the Biological and Medical Sciences (Philadelphia and London: W. B. Saunders, 1967), p. iv.
} 